\title{
Formation of legislation on pension insurance in France, Great Britain, and Russia. A retrospective
}

\section{Formación de la legislación sobre el seguro de pensiones en Francia, el Reino Unido y Rusia. Una retrospectiva}

DOI: https://doi.org/10.17981/juridcuc.18.1.2022.06

Fecha de Recepción: 2021/05/17. Fecha de Aceptación: 2021/10/27

Anna V. Aleksandrova

Penza State University. Penza (Russian Federation) anna.v.aleksandrova@bk.ru

Angelina V. Lapaeva

Tambov State University named after G. R. Derzhavin. Tambov (Russian Federation) angelina.v.lapaeva@mail.ru

\section{Anastasia A. Ryzhova}

Penza State University. Penza (Russian Federation) anastasia.a.ryzhova@mail.ru

\section{Elena A. Serebryakova}

National Research University Higher School of Economics. Moscow (Russian Federation) elenaaserebryakova@yandex.ru

Para citar este artículo:

Aleksandrova, A., Lapaeva, A., Ryzhova, A. \& Serebryakova, E. (2022). Formation of legislation on pension insurance in France, Great Britain, and Russia. A retrospective. Jurídicas CUC, 18(1), 135-154. DOI: http://dx.doi. org/10.17981/juridcuc.18.1.2022.06

\section{Resumen}

El estudio analiza la crisis de los sistemas modernos pensionales y establece la necesidad de cambiar el paradigma de la legislación de pensiones. El objetivo del estudio consiste en identificar las características de la legislación sobre los seguros pensionales de varios estados (Francia, Reino Unido y Rusia) partiendo de su etapa inicial hasta 1914. La novedad se expresa tanto en la formulación del problema como en la metodología de investigación (selección de países y período de estudio, justificación de la aplicación de los métodos: dialéctico, de análisis, de síntesis, sistémico-estructural, sociológico, estadístico, histórico-legal, comparativo-legal, formal-legal). Como resultado del estudio se llegó a conclusiones sobre el condicionamiento histórico de las características de la formación de la legislación sobre el seguro de pensiones de un país en particular. En Francia, se promulgó una legislación temprana sobre el seguro de pension voluntario y también obligatorio en Francia. En el Reino Unido, durante el período que se examina, no había legislación sobre seguros de pensiones, a pesar del desarrollo temprano de las instituciones pertinentes dentro de los talleres, gremios y, posteriormente, dentro de la actividad de los sindicatos y las "sociedades fraternales». En Rusia, debido a la naturaleza agraria de la economía, el seguro de pensiones en el marco de los talleres y gremios nunca funcionó; en 1914 se adolecía de leyes sobre el seguro de vejez, mientras que los riesgos de discapacidad y la pérdida del sostén de la familia se regulaban por ley.

Palabras clave: Pensión; seguro; ley; empleado

\section{Abstract}

The relevance of the study is due to the crisis of modern pension insurance systems and the need to change the paradigm of pension legislation development. The purpose of the study is to identify the features of the formation of legislation on pension insurance in several countries (France, Great Britain, and Russia) at the initial stage of development (before 1914). The novelty is expressed both in the formulation of the problem and in the research methodology (the choice of countries and the period of research, the justification for the use of methods: dialectics, analysis, synthesis, system-structural, sociological, statistical, historical-legal, comparative-legal, formal-legal). The result of the study was the conclusions about the historical conditionality of the peculiarities of the formation of legislation on pension insurance in a particular country. There was early legalization of both voluntary and compulsory pension insurance in France. There was no legislation on pension insurance in the UK during the period under review, despite the early development of relevant institutions in the framework of workshops, guilds, and later in the framework of trade unions and "friendly societies". In Russia, due to the agrarian nature of the economy, pension insurance did not develop within the framework of workshops and guilds; there were no laws on insurance in case of old age by 1914, while the risks of disability and loss of the breadwinner were regulated by law. Keywords: Pension; insurance; law; employee 


\section{INTRODUCTION}

The relevance of the historical and legal study of the legislation on pension insurance is due to the following factors:

- The crisis of modern pension insurance systems and attempts to overcome it through pension reforms (Hernández, 2016).

- The crisis of the "welfare state" model as a whole, which appeared at the end of the twentieth century (Rosanvallón, 2021), the search for other models of the welfare state.

- Strengthening the flexibility of social legislation under the influence of neoliberal economic doctrine (Bonet, 2018).

- Recognition of the importance of the conceptual foundations of the pension system in Russia, which is confirmed by the inclusion of these principles in Article 75 of the Constitution of the Russian Federation in 2020 (Shashkova, Verlaine \& Kudryashova, 2020).

The coronavirus pandemic, associated economic constraints, and problems with financing pension insurance have further exacerbated preexisting problems. The need to change the paradigm of pension protection is becoming obvious today.

The development of new principles that can form the basis of pension legislation is impossible without studying the existing experience of Russia and foreign countries in the field of pension provision.

In this regard, the purpose of this study is to identify the features of the formation of legislation on pension insurance in several states (France, Great Britain, and Russia) at the initial stage (before 1914). The choice of the countries mentioned above is not accidental. By the beginning of the twentieth century, France, Great Britain, and Russia were not only among the leading states (in political and socioeconomic terms), but also embodied individual models of pension provision in their legislation in different ways. The article examines the period up to 1914: it was at this initial stage that the system of voluntary pension insurance was formed in most European countries, and laws on compulsory pension insurance of employees were adopted in several countries. 


\section{Discussion}

\section{Methods}

A methodology has been developed to study the historical and legal aspects of the formation of insurance pension legislation. It involves the use of the following methods:

- General dialectical method (consideration of legislation on pension insurance in the process of its emergence and development, in conjunction with other branches of legislation).

- General scientific methods: analysis (a division of the subject of research into its parts, namely, a separate study of English, French and Russian legislation), synthesis (subsequent connection of the studied elements together, identification of common and special features in them), system-structural method (consideration of the pension legislation of each country as an element of a larger system - the system of national legislation).

- Private scientific methods developed by individual non-legal sciences: sociological (using data from sociological studies to evaluate the results of pension reforms), statistical (using statistical data to identify the percentage of persons covered by pension insurance);

- Private-law methods developed by legal science: formal-legal analysis of normative-legal acts and other sources of pension law; comparative-legal (comparison of acts of pension legislation of Great Britain, France and Russia, adopted in the period before 1914); historical-legal (identification of features of the formation of legislation on pension insurance, due to the specifics of the historical period, socio-political situation and national-cultural traditions of a particular country).

\section{RESUlts}

Social insurance in France has deep historical roots and its traditions (which is, perhaps, the reason for maintaining the multiplicity of pension insurance regimes today). On the one hand, it is associated with life insurance: the tontine, which was a kind of combination of life insurance, life support, and a government loan, 
was legislatively consolidated in France in the 17th century. On the other hand, pension insurance grew out of the medieval workshop mutual friendly society, the experience of which was the basis for the relevant legislation, which first regulated the activities of pension insurance funds voluntarily, and at the end of the considered stage established a system of mandatory pension insurance for workers and peasants. At a certain stage of development associated with bourgeois revolutions (late 18th - early 19th centuries), the activities of mutual insurance societies were threatened by the prohibition of corporations, labor unions, and associations. Starting from the middle of the 19th century, the state, on the contrary, began to support these societies, regulating their activities by law, including in some cases in the financing process or placing them under the tutelage of municipal authorities. In 1910, the pension law for workers and peasants was adopted in France, which introduced the beginning of mandatory pension insurance, but it was not widely used, since many employees evaded paying contributions, employers were also not interested in encouraging employees to do this, pension savings were devalued due to inflation.

The history of the English pension system has been mainly concerned with measures to prevent poverty in old age. It was characterized by the early formation of a system of public charity for the elderly and other disabled persons. The following features were characteristic of the pension insurance of Great Britain at the considered stage: the rather early formation of its organizational foundations within the framework of workshops and guilds; restrictions in the functioning of its institutions associated with the prohibition of workers' coalitions at the turn of the 18th-19th centuries; the significant role of "friendly societies" and trade unions, which were traditionally strong in Great Britain; the lack of legislative registration of pension insurance, regulated by internal acts of trade unions and mutual insurance societies or customs; the widespread use of voluntary social insurance (it covered a quarter of the country's population by the end of the 19th century). The Law of 1897 regulated the insurance of workers against industrial accidents. 
The UK adopted the old-age pensions Act in 1908, which was based on the principle of state (budget) financing of pensions: the right to a pension was conditioned by several requirements (high retirement age, need).

Assistance to the disabled in Russia in the Middle Ages was provided in the form of state, church, and public charity. In the 19th century, legislation on the formation of pension savings within the framework of old-age insurance saving banks, established in various branches of activity under the patronage of the state, received significant development. There was also a legislative regulation of the activities of charitable foundations and cash registers aimed at providing workers with pensions. Russian legislation on pension insurance by the beginning of the First World War was also at a fairly high level of development, as evidenced by the existence of laws (1912) aimed at creating insurance funds based on mandatory contributions from employees and employers and providing payments in the event of disability (due to illness, injury) or death of a worker. Reaching the retirement age (old age) was not considered by the Russian pension legislation of that period as a social risk and did not give the right to a pension, although ideas about such a pension were expressed in the course of legislative work.

\section{Formation of the French legislation on pension insurance}

Pension insurance was originally formed as life insurance in France. One of the first forms of such insurance was a life annuity. The mention of such rent is already found in the ordinances of the fourteenth century (Laurière, 1757, ord. 1308). The life-annuity has maintained its importance as one of the ways of self-sufficiency of the subjects for several centuries. However, it was only available to the wealthy.

The life-annuity received a new development in the 17th century due to the institution of a tontine (named after Tonti, the founder of this form of annuity). Tontine was defined as a kind of mutual insurance in which each member of the association shall contribute 
a certain amount to the general fund to subsequently receive interest from it. In the event of the death of a tontine member, the income from the contribution was distributed among the surviving members of the association. In the $1650 \mathrm{~s}, \mathrm{~L}$. Tonti suggested that the Controller General of Finances of France use such an association as a kind of government loan. "Tontine loans" are considered the beginning of modern life insurance, as they were the first to use actuarial calculations (Khmelevskaya et al., 2018).

The first royal tontine was established in France by an edict of 1689 (De Beamont, 1766). The tontine participants were divided into 14 age groups. After the death of each participant, the interest continued to be distributed among the members of his/her group. This happened until the death of the last rentier in the group, after which the state was exempt from continuing payments.

Further, the state created at least ten tontines. Mainly, this institution was in demand among the wealthy circles of society and was practically not used among the working people.

The last royal tontine was created in France in 1759 (Dehais, 1861). Since the middle of the 17th century, private tontines began to develop: more than 20 tontines were created in France in 17901800 (Thiveaud, 1997). Many of these organizations went bankrupt, unable to guarantee the payment of rent to customers. In this regard, at the beginning of the 19th century, Napoleon Bonaparte imposed a ban on the establishment of such organizations without the special consent of the emperor (Conseil d'état, 1809).

The change in the state's approach to social responsibilities was strongly influenced by the French Revolution (Desgré, 2018). The decree of March 19, 1793 (Duvergier, 1825) provided for the creation of a National Social Insurance Fund, but real steps in this direction were taken only after the fall of Napoleon's empire. In 1818, the Paris Savings and Social Insurance Fund was established. The amounts paid for social security purposes were limited to a certain "ceiling" (initially it was 600 francs per week). Statistics show that workers contributed only small amounts to the savings bank (Gérando, 1839). 
The provision of workers who have lost their ability to work, including due to old age, has traditionally been carried out by a voluntary mutual friendly society created on a professional basis (within guilds, workshops). In the Middle Ages, their activities were regulated by the norms of ordinary and corporate law.

At the turn of the 18th-19th centuries, the activities of the friendly society were jeopardized by the adoption of the famous Le Chapelier law in 1791 (Ado, Nikolaevna, Pimenova \& Chertkova, 1992), formally directed against corporations, but criminalizing the organization of workers' unions (including trade unions and self-help societies).

The state in France refused to persecute workers for organizing unions only in the middle of the 19th century. A law was passed on July 15, 1850, that regulated the foundations of the activities of the mutual friendly society and established the guardianship of the municipal authorities over them.

Also, a law was passed in 1850 (dated june 18) on the establishment of a Pension Fund for old age with the support of the state. This law provided for the accumulation of funds of the mutual friendly society to provide workers with payments in case of old age (after they reach 50 years). Citizens could make voluntary contributions to the pension funds to receive payments upon reaching the specified age. The maximum annual payment was 1.000 francs (Thiveaud, 1997). An important innovation of the law was the subsidiary participation of the state in the financing of the pension fund.

These provisions were further improved by the Law on the National Old Age Pension Fund (Loi du 20 juillet 1886): the state was declared the guarantor of the pension fund. The maximum annual payment was increased to 1.200 francs. The principle of voluntary admission to the cashier was retained. The size of the pension was made dependent on the number of contributions. The condition for the appointment of a pension was age (50 years), or serious injury or disability for another reason.

By the end of the 19th century, the policy of supporting mutual insurance companies gave positive results. In 1897, in France, 
226.491 people received a pension totaling more than 34 million francs. The contributions of the members of the National Pension Fund for old age in 1897 amounted to 43.679 .637 francs (Köppen, 1900). However, nationwide, the number of pensioners was insignificant: in 1901, the population in France was 39 million people (Ostrikov \& Wandel, 1989a), that is, the number of pension recipients was no more than $0.6 \%$.

It was obvious that the low level of wages of most workers did not allow them to participate in the formation of pension savings. It was necessary to involve employers in the financing of insurance funds. At the end of the 19th century, France adopted laws on compulsory insurance of workers in certain industries (for example, the law of 1894 on compulsory insurance of mine workers, according to which both the employee and the employer were obliged to pay a monthly insurance premium (Loi du 29 juin 1894).

In 1910, the law on pensions for workers and peasants was passed in France as a result of a long political struggle (Loi du 6 avril 1910). This law provided for mandatory pension insurance for employees whose earnings did not exceed 3.000 francs per year. Contributions were to be paid on a parity basis by employees and employers. Subsidiary participation of the state was provided for in the financing of pensions. The employee acquired the right to receive payments from the state, provided that they made at least 30 annual contributions. The age of receiving a pension was set at 65 years, later (in 1912) it was reduced to 60 years.

This law was only partially implemented: many employees evaded paying insurance premiums, also, inflation contributed to the depreciation of accumulated amounts. By 1913, only 10\% of the French population was covered by social insurance (Dreyfus, Ruffat, Viet \& Voldman, 2006).

Thus, pension insurance in France has a long history, dating back to the Middle Ages. By the beginning of the twentieth century, it was predominantly voluntary. At this stage, it has not yet been possible to cover a significant part of the workers with mandatory pension insurance. 


\section{Features of pension insurance in the UK}

at the initial stage of its development

The earliest indications of the organization of insurance within the guilds and workshops in England date back to the tenth century. To a certain extent, the workshops provided for their members in the event of illness, death, disability, and unemployment.

Personal and property insurance was formed in the Middle Ages. Personal insurance provided for the payment of benefits in the event of death, illness, or disability: payments for burial, for the support of widows and orphans were among them (Khmelevskaya et al., 2018). Personal insurance is closely related to pension insurance, since "insurance of widowhood and orphanhood is nothing more than life insurance or insurance in case of death" (Vigdorchik, 1912, p. 114).

After the fire of 1666, fire insurance began to develop in London (Khmelevskaya et al., 2018). Two joint-stock companies were organized in 1720 (London Assurance Corporation and Royal Exchange Assurance), which, in addition to the fire and sea insurance, were engaged in life insurance. Such insurance companies were largely "pioneers", developing methods of life insurance based on statistical data and mathematical methods (Roik, 2020).

The development of capitalism in England was accompanied by the destruction of the workshop system and the emergence of a significant mass of the proletariat. These people were completely deprived of any support in the event of disability. The workers begin to create voluntary insurance organizations unable to count on the help of the workshop or the parish. According to Zachinskii (1906), mutual assistance of workers originated and reached its greatest development in England.

English mutual friendly society that emerged in the late 18th and early 19th centuries can be divided into two types. The first is the so-called "friendly societies", which set themselves no other tasks than mutual assistance in strictly defined cases. The second was the trade unions, the main task of which was to fight for the rights of workers, but, also, they took on the functions of mutual insurance. 
Most of the organizations of the first type, "friendly societies", were limited only to insurance in case of illness or death of its participants. These societies were usually simple savings banks. Nevertheless, they served as a "prototype of the future of social insurance on a mandatory (public) basis" (Roik, 2020, pp. 34-35).

In the 19th century, "friendly societies" became widespread in Great Britain: in 1892, the number of persons participating in them amounted to 8.320.262 people, and the capital reached 2.600.3031 pounds sterling (Roik, 2020). The population of Great Britain in these years (according to data for 1891) was about 33.000.000 people (Ostrikov \& Wandel, 1989b), that is, this kind of insurance was covered by a quarter of the country's population. However, the drawback in the activities of the "friendly societies" was that they were limited to insurance in case of illness and payment of burial allowances. Also, a significant part of the members of the "friendly societies" was among the well-off segments of the population, who did not belong to the working class.

Social insurance provided by trade unions was much better organized and covered a wider range of risks: unemployment, illness, disability, accident. Therewith, payments made by large trade unions could be very significant (Zachinskii, 1906). However, trade union social insurance also had its drawbacks: it covered only high-paid workers; regular payments of benefits could not always be guaranteed, as trade union funds could be spent on strikes or devalued during economic crises. For example, the benefit-society of stonecutters during the 60 years of its existence repeatedly came to complete bankruptcy (Zachinskii, 1906).

Nevertheless, the need for such societies in the period under review was extremely great. They were created even when the activity of trade unions was prohibited (in the late 18th - early 19th centuries). In England, as well as in France, laws were passed (two Acts on the Coalitions of 1799 and 1800 - Combination Laws), under threat of criminal liability, prohibiting the creation of workers' organizations (Lukin \& Dalin, 1934). 
The laws against coalitions were repealed in 1824 under pressure from the labor movement. However, trade unions still did not have the rights of a legal entity, which prevented them from fully defending their rights in court. The legalization of trade unions became possible only with the adoption of the Law of 1871 (Trade Union Act 1871, 1992).

In the 19th century, the UK did not pass a law on pension insurance in case of old age or loss of the breadwinner. Only the Law of 1847 on the liability of the employer for an accident that occurred as a result of his/her conscious intention or obvious negligence was adopted. Therewith, the burden of proof was attached to the injured worker. Only the law of 1897 changed the situation, establishing the responsibility of the entrepreneur for all accidents that caused the loss of working capacity of the worker for more than 2 weeks. This act was a significant step forward in the development of British social legislation. One of the consequences of its application was that entrepreneurs began to insure their employees in private insurance companies. Trade unions, in turn, were exempt from the need to ensure their members against accidents; however, insurance against other social risks remained their function. Therewith, old-age insurance remained "unaffordable and difficult" for most of the unions, as it required significant funds. In this regard, the Congress of British Trade Unions adopted a resolution on the need for a state organization of insurance in case of old age, financed "from the general tax falling on all classes" (Zachinskii, 1906, pp. 12-13). The draft law on state pension provision, funded by taxes, and was eventually passed in 1908. Thus, the insurance principles of pension provision did not receive their consolidation in British law in the period before 1914.

\section{Formation of the Russian legislation on pension insurance}

The predominantly agrarian nature of the Russian economy at this stage led to the fact that such a developed system of workshop mutual assistance, as it was in France and Great Britain, did not 
develop in Russia; family and community assistance for a long time have remained the main forms of support for the elderly and other people in need.

Only in the last quarter of the 19th century, pension insurance in Russia received its normative consolidation. One of the first regulations governing social insurance was the Regulation on the mining population (Dehais, 1861), which provided for the establishment of special partnerships at mining plants to provide for workers in case of illness and old age. According to the Regulations, auxiliary funds were established at each large factory or mine, from which temporary and permanent benefits were paid, including pensions to members of the partnership, their widows, and orphans.

In the following decades, similar regulations were adopted concerning persons employed in other fields of activity: on state railways (Collection of the Management of the pension fund of employees on state railways, 1896), in credit institutions (Regulations on pension funds of employees and workers, 1897). The provisions could provide for both voluntary and mandatory participation in the pension funds of workers or employees. When it came to state (state-owned) enterprises, the regulations provided for participation in the financing of the state treasury's cash registers.

In the 1880s, several petitions were sent to the Russian government for the development of mandatory social insurance projects prepared by liberal institutions (Vigdorchik, 1912). The result of such appeals was the creation of government commissions that had been developing mandatory insurance projects for about 20 years.

In 1903, Russia approved Temporary Rules on pensions for workers of state-owned mining plants and mines who lost their ability to work, according to which the injured workers or their family members could be paid pensions from the treasury (Provisional Regulations on pensions to workers of state mining plants and mines, 1903). 
The adoption of laws (in the strict sense of the word) on social insurance became possible after the establishment of the parliament in Russia in 1906 - the State Duma. The result of many years of work on bills on social insurance was a legislative package adopted on June 23, 1912: "On providing workers in case of illness", "On insurance of workers against accidents at work", "On the approval of the Council for workers' insurance", "On the approval of the presence for workers' insurance". According to these acts, health insurance funds were created in enterprises with the number of workers of at least 200 people. Workers who paid contributions to these funds acquired the rights to benefits in connection with illness, injury, death, and childbirth. Cash registers were managed on a parity basis jointly by workers and employers. Funding was provided by contributions from workers $(3 / 5)$ and employers (2/5).

The Law "on Insurance of Workers against Accidents at work" (Act June 23, 1912) established for workers affected by such cases, pensions for incapacity for work and the loss of a breadwinner. The payments to the victims were made from the funds of insurance partnerships in the form of benefits and pensions, and payments to their family members were made only in the form of pensions. The number of payments was determined as a percentage of the employee's annual salary. If the worker was completely unable to work, the pension was paid to him/her in the amount of $2 / 3$ of the annual salary, and if it was incomplete - in the amount of the share of $2 / 3$ of the annual salary that corresponded to the degree of disability. If less than $5 \%$ of the working capacity was lost, the right to a pension did not arise.

The following should be noted concerning old-age pension provision. The draft law developed in 1905 by the Ministry of Finance, among other grounds, provided for social insurance in the event of disability and old age. However, its introduction to the parliament was prevented by the dissolution of the State Duma. Subsequently, various projects were proposed, prepared taking into account the views of legislators, government authorities, and industrialists. As 
a result, by 1912, "the bill on state insurance of workers against old age and disability, developed in 1905, disappeared" (Levshuk, 2011, p. 133). Thus, mandatory pension insurance in the event of old age was not fixed in the pre-revolutionary Russian legislation. Disability insurance was provided only if it was the result of an accident at work.

Among the shortcomings of the laws of 1912, it is necessary to mention the limited scope of their action: they did not extend to the entire territory of the country (but only to the European part and the Caucasus), to enterprises with a certain number of workers and with certain equipment. The 1912 Law "On Insurance of Workers Against Industrial Accidents" covered approximately 15\% of the total number of workers in Russia (Machulskaya \& Gorbacheva, 2001).

Nevertheless, social insurance has become quite widespread even under such conditions. By 1917, several thousand insurance companies had been established in Russia (Roik, 2020).

\section{Conclusions}

The legislation on pension insurance has a long history, it is not an invention of the twentieth century. The modern approach to understanding a pension as a regular monetary provision to citizens who have been engaged in a certain professional activity for a certain period and (or) have reached a certain age, as well as to citizens recognized as disabled or who have lost a breadwinner, has not developed immediately. At the initial stage, a person could acquire the right to receive certain payments in old age either while in state and military service (this aspect does not apply to pension insurance and is not considered in this article, it can become the subject of independent research) or through membership in insurance funds, mutual friendly societies, activities of which were based on civil law principles. The essential differences between such elements of pension provision as pension insurance and state (budget) provision have led to the use of different methods of legal regulation in rela- 
tion to them. If dispositive methods initially prevailed in the sphere of regulation of the organization and activity of insurance pension funds, then in the field of pension provision for military personnel and officials -imperative ones prevailed. The introduction of mandatory pension insurance at the turn of the 19th-20th centuries leads to a mixed, complex regulation, using both dispositive and imperative methods (which is a specific feature of the method of social security law today).

The study allowed us to identify the following features of the formation of legislation on pension insurance:

- The early formation of pension legislation in France, associated with attempts by the state to regulate life insurance issues, as well as the activities of voluntary mutual insurance societies.

- The absence in the UK of legislative regulation of pension insurance issues until the 20th century; the widespread use of voluntary social insurance, the regulation of which was carried out based on the norms of corporate and customary law.

- The late formation of pension insurance institutions in Russia, associated with the predominantly agrarian nature of the economy until the end of the 19th century; the absence of compulsory old-age pension insurance in the pre-revolutionary (before 1917) period.

\section{Funding}

The study was carried out with the financial support of the Russian Foundation for Basic Research in the framework of scientific project No. 20-011-00252.

\section{ACKNOWLEDGMENTS}

The reported study was funded by the RFBR, project number 20-011-00252. 


\section{REFERENCES}

Ado, A., Nikolaevna, N., Pimenova, L., Fedosova, E., Chertkova, G. (Comp.). (1992). Le Chapelier Law. In, A. Ado, Documents of the history of the Great French Revolution [Vol. 2, pp. 44-45]. Moscow: House of Moscow State University.

Bonet, A. M. (2018). Derechos sociales, normas de acceso y democracia. La agenda de los derechos humanos para una convivencia solidaria. Revista Latinoamericana de Derecho Social, (26), 3-27. http://dx.doi.org/10.22201/ iij.24487899e.2018.26.11858

Conseil d'état. (1 $1^{\text {er }}$ avril 1809). Avis du Conseil d'état sur les associations de la nature des tontines. Bulletin des lois de l'Empire Français: 4e série. Tome 10.

De Beamont, S. (1766). Jurisprudence des rentes: ou Code des rentiers, par ordre alphabétique. [2 éd.]. Paris: Chez Guillyn.

Dehais, E. (1861). L'assurance sur la vie en France et les tontines. Paris: Guillaumin.

Desgré, S. (2018). Un autre regard sur l'histoire de la protection sociale en France entre 1789 et 1945: réflexions scientifiques à partir d'une expérience professionnelle de biographe d'institutions sociales. [Thèse sur travaux]. L'Université de Nantes, Nantes, France. Disponible sur http://www. theses.fr/2018NANT2062

Dreyfus, M., Ruffat, M., Viet, V. \& Voldman, D. (2006). Se protéger, être protégé: Une histoire des assurances sociales en France. Rennes: Presses universitaires de Rennes. http:// dx.doi.org/10.4000/books.pur.6879

Duvergier, J. B. (1825). Décret du 19 mars 1793 concernant la nouvelle organisation des secours publics. In, J. Duvergier, Collection complète des lois, décrets, ordonnances, règlements, et avis du Conseil d'Etat. [Vol. 5, pp. 255-256]. Paris: A.Guyot et Scribe. 
French Republic. (21 juillet, 1886). Loi du 20 juillet 1886 relative a l'organisation de la caisse nationale de retraites pour la vieillesse : gestion, institution d'une commission superieure chargee de toutes les questions qui concernent la caisse nationale des retraites pour la vieillesse, capital et versement des rentes viageres, liquidation de la pension, remboursement, gestion des fonds de la caisse nationale des retraites. Journal Officiel de la République Francaise-JORF. Disponible sur https://www.legifrance.gouv. fr/jorf/id/JORFTEXT000000877358

French Republic. (29 juin 1894). Loi du 29 juin 1894 sur les caisses de secours et de retraites des ouvriers mineurs. Bulletin de l'Inspection du travail, No. 1. Disponible sur https://www.legifrance.gouv.fr/jorf/id/JORFTEXT000000692411

French Republic. Président de la République. (5 avril 1910). Loi sur les retraites ouvrières et paysannes. Journal officiel de la République française. Disponible sur https://travail-emploi.gouv.fr/IMG/pdf/Loi_sur_les_retraites_ouvrieres_et_ paysannes-3.pdf

Gérando, J.-M. (1839). De la bienfaisance publique. [Vol. 2]. Belgium: Société belge de librairie.

Hernández, J. R. (2016). La justicia social desde un nuevo enfoque de la justicia. Análisis del mandato de la Organización Internacional del Trabajo conforme al concepto moderno de la justicia (Segunda parte). Revista Latinoamericana de Derecho Social, (22), 101-160. http://dx.doi.org/10.1016/j. rlds.2015.03.001

Khmelevskaya, S. A., Ermakov, D. N. Aranzhereev, M. M., Kuzin, A. A., Machekhin, V. A., Orlova, I. Y., Smolnikova, E. V., V, S., Khmelevsky, S. V., Khmyrov V. V. (2018). Pension insurance: philosophy, history, theory, and practice. Moscow: Dashkov and Co. 
Köppen, A. P. (1900). Social legislation of France and Belgium. St. Petersburg: Typography named after I.

Laurière, E. (1757). Ordonnance touchant le payement des rentes à vie. In, E. Laurière, Ordonnances des Roys de France de la troisième race [Ord. 1308, pp. 456-457]. Paris: Imprimerie royale.

Levshuk, M. V. (2011). Formation of the legal basis for pre-revolutionary state pension provision. Scientific Bulletin of Belgorod State University, Series: Philosophy. Sociology. Right, 14, 125-138.

Lukin, N. M. \& Dalin, V. M. (Eds.). (1934). Law against workers' coalitions 1799. New history in documents and materials. Moscow: Sotsekgiz.

Machulskaya, E. E. \& Gorbacheva, Zh. A. (2001). Social Security Law: A Study Guide. Moscow: Knizhnyi mir.

Ostrikov, P. I. \& Wandel, P. P. (Comp.) (1989a). Collection of documents on the history of modern times. Economic development and domestic policy of the countries of Europe and America, 1870-1914. Moscow: Vysshaya shkola.

Ostrikov, P. I. \& Wandel, P. P. (Comp.) (1989b). The population of Great Britain and Ireland. In Collection of documents on the history of modern times. Economic development and domestic policy of the countries of Europe and America, 1870-1914. Moscow: Vysshaya shkola.

Russian empire. (july 11, 1912). On Insurance of Workers against Accidents at work. Collection of legalizations, Dept. I., Art. No. 1230.

Russian empire. (june 2, 1903). Provisional Regulations on pensions to workers of state mining plants and mines who have been disabled in the factory or mine work. Complete collection of laws of the Russian Empire. Collection (18811913). Vol. 21, Art. No. 20087. 
Russian empire. (June 13, 1897). Regulations on the pension funds of employees and workers in private credit institutions, trade, and industrial enterprises, and insurance companies. Complete collection of laws of the Russian Empire. Third collection. Vol. 17, Art. No. 14306.

Russian empire. (1896). Collection of management of the pension fund of employees on state railways. St. Petersburg: M-vo.

Roik, V. D. (2020). Pension insurance and security. Moscow: Urait. Rosanvallón, P. (2021). New social question. Rethinking the welfare state. Princeton: Princeton University Press.

Shashkova, A., Verlaine, M. \& Kudryashova, E. (2020). On Modifications to the Constitution of the Russian Federation in 2020. Russian Law Journal, 8(1), 60-83. https://doi. org/10.17589/2309-8678-2020-8-1-60-83

Thiveaud, J.-M. (1997). La lente construction des systèmes de retraite en France de 1750 à 1945. Revue d'économie financière, 40(2), 21-54. Disponible sur https://www.persee.fr/ doc/ecofi_0987-3368_1997_num_40_2_2305

United Kingdom of Great Britain and Northern Ireland. (1992). Trade Union Act 1871. [No. 22 of 1941]. Available: https:// www.ilo.org/dyn/natlex/natlex4.detail?p_lang=es\&p_ isn $=98373 \& p \_$classification $=02$

Vigdorchik, N. A. (1912). Social insurance: a systematic presentation of the history, organization, and practice of all forms of social insurance. St. Petersburg: Prakt. Meditsina. Available: https://1lib.mx/book/5350358/ e3697f?id=5350358\&secret $=$ e3697f

Zachinskii, L. (1906). Insurance for workers in the West. St. Petersburg: Knigoizdatelstvo "Molot. 
Anna V. Aleksandrova. Ph.D. in Law, Penza State University (Russian Federation). https://orcid.org/0000-0003-0747-8675

Angelina V. Lapaeva. Ph.D. in Law, Tambov State University named after G.R. Derzhavin (Russian Federation). https://orcid. org/0000-0002-9430-5344

Anastasia A. Ryzhova. Ph.D. in Law, Penza State University (Russian Federation). https://orcid.org/0000-0003-0166-4469

Elena A. Serebryakova. Ph.D. in Law, National Research University Higher School of Economics (Russian Federation). https://orcid. org/0000-0002-4152-3655 